\title{
PENGEMBANGAN PRODUKSI PESTISIDA ALAMI \\ DARI Beauveria bassiana DAN Trichoderma sp. MENUJU PERTANIAN ORGANIK
}

\author{
Herry Purnama ${ }^{1}$, Nur Hidayati ${ }^{1}$, dan Eni Setyowati ${ }^{2}$ \\ ${ }^{1}$ Program Studi Teknik Kimia, Fakultas Teknik \\ ${ }^{2}$ Program Studi Ilmu Ekonomi dan Studi Pembangunan, Fakultas Ekonomi dan Bisnis \\ Universitas Muhammadiyah Surakarta \\ Jl. A. Yani Pabelan-Kartasura, Surakarta 57102 \\ Email: hp269@ums.ac.id
}

\begin{abstract}
Recently the condition of agriculture in Indonesia needs to be addressed. Soil fertility getting damaged due to chemical fertilizer that is not impartial. In addition, the impact of excessive use of synthetic pesticides can cause damage to the ecosystem. Control of plant diseases using biological agents began getting attention because of public concerns due to the use of synthetic chemical pesticides. Biological agents are microorganisms, both naturally occurring such as bacteria, fungi, viruses and protozoa, as well as the results of genetic engineering that are used to control plant pests. Madrasah Diniyah Jumapolo, Karanganyar, has pioneered the manufacture of biological agents to support organic farming although on a small scale. Community service activities undertaken to provide assistance in the improvement of the production process and management improvements. The technology developed is the use of biological pesticides agent isolated from Beauveria bassiana and Trichoderma sp. as a natural insecticide and fungicide. The activities received support from the madrasa and expressed successfully produce biological agents in the proper packaging. In addition to the consumption of madrasa and nearby farmers, pesticide product of biological agents is also sold to the public. The selling of products will increase the development of organic farming to produce healthy food also will gain additional income for the madrasa.
\end{abstract}

Kata-kata kunci: agen hayati, pestisida, insektisida, B. bassiana, Trichoderma sp

\section{PENDAHULUAN}

Madrasah Diniyah Jumapolo berlokasi di Dusun Sembuh Wetan RT 02/ RW 05, Desa Kwangsan, Kecamatan Jumapolo, Kabupaten Karanganyar. Jarak antara lokasi kegiatan dengan Universitas Muhammadiyah Surakarta sekitar $40 \mathrm{~km}$.
Madrasah ini sudah berdiri sejak 1988 di atas lahan seluas 1 ha dan memberikan pelayanan pendidikan (khusus untuk putra) setaraf SD hingga SMA. Sistem pendidikan yang ditawarkan adalah boarding school atau seluruh siswa/santri harus masuk ke dalam asrama. Saat ini jumlah santri yang sedang 
menimba ilmu sekitar 200 orang yang berasal dari berbagai wilayah termasuk dari luar Jawa. Madrasah dipimpin oleh seorang Direktur sebagai Kepala Sekolah dan dibantu oleh sejumlah guru/ustadz sebanyak 32 orang. Keberadaan madrasah ini menjadi sangat penting mengingat peranannya dalam memajukan dunia pendidikan melalui sistem pendidikan yang terpadu dan aplikatif. Keunikannya terletak dalam paduan kurikulum pendidikan ilmu agama dan ilmu umum, di samping para santri juga dibekali keterampilan dasar seperti bercocok tanam secara organik. Lebih unik lagi ternyata Madrasah Diniyah Jumapolo tidak menjadikan faktor finansial sebagai prasyarat utama dalam mengikuti pendidikan.

Pendidikan di madrasah menitikberatkan pada ilmu-ilmu agama khususnya kajian terhadap Al-Quran dan Al-Hadits. Mengingat lokasinya berada jauh di pedesaan, Madrasah Diniyah Jumapolo membentuk Divisi Pertanian. Divisi ini mengajari para santri untuk bertani secara organik untuk berbagai komoditi seperti padi, ubi, kacang-kacangan dan sayur-sayuran. Meskipun hanya dengan peralatan yang sangat terbatas, divisi ini telah dan atau/ sedang mengembangkan teknologi pedesaan khususnya di bidang pertanian organik. Dalam pertanian organik dihindari penggunaan bahan kimia (pestisida) yang sangat berpotensi mengganggu kesehatan manusia dan mencemari lingkungan sekitar.

Teknologi yang sudah dan akan dikembangkan adalah pemanfaatan pestisida agen hayati yang diisolasi dari Beauveria bassiana dan Trichoderma sp. sebagai insektisida dan fungisida alami. Selain untuk konsumsi madrasah dan petani sekitar, produk pestisida pestisida agen hayati ini juga dijual kepada umum. Bahkan beberapa kali produk alami ini juga dipesan oleh warga di luar wilayah Kecamatan Jumapolo. Dengan adanya penjualan produk agen hayati tersebut, maka selain membantu pengembangan pertanian organik untuk menghasilkan pangan yang sehat juga akan mendapatkan keuntungan sebagai tambahan pemasukan bagi madrasah. Selama ini biaya operasional penyelenggaraan pendidikan di madrasah sebagian besar berasal dari para donatur.

Di sisi lain, rencana pengembangan produk agen hayati terkendala oleh faktor klasik, yaitu masalah pendanaan. Untuk bisa memproduksi dan melayani pemesanan produk tersebut diperlukan berbagai peralatan utama dan pendukung. Madrasah memiliki keterbatasan modal dan peralatan untuk memproduksi agen hayati tersebut. Bertolak dari hal di atas, maka Tim Pengabdian Masyarakat Universitas Muhammadiyah Surakarta membantu dan memberikan pendampingan dalam rangka meningkatkan kapasitas produksi dan kualitas agen hayati tersebut.

Berdasarkan hasil diskusi antara Tim dengan pihak Madrasah Diniyah Jumapolo, maka telah diidentifikasi permasalahan yang ada di lokasi kegiatan. Permasalahan utama adalah keterbatasan dalam hal: (1) pengetahuan untuk membuat agen hayati yang berkualitas, (2) peralatan pendukung untuk produksi agen hayati dalam skala lebih besar, (3) pengetahuan dalam hal bisnis dan manajemen. Untuk mendapatkan hasil terbaik, produksi agen hayati membutuhkan peralatan dan pengkondisian secara khusus seperti layaknya sebuah laboratorium mikrobiologi yang standar. Peralatan standar antara lain autoklaf (untuk sterilisasi media dan peralatan), mikroskop (untuk analisis fisiologis jamur), dan centrifuge (untuk memisahkan spora jamur). Peralatan penunjang produksi yang seharusnya diadakan adalah mesin penggiling dengan keluaran 80 mesh dan juga mesin pengepak. Dengan adanya peralatan-peralatan tersebut maka diharapkan permasalahan di bidang 
produksi dapat diatasi, baik secara kualitas dan kuantitas.

Selain peralatan, pemahaman dan penguasaan ilmu mikrobiologi juga perlu ditingkatkan termasuk standar dan operasi penggunaan peralatan. Para santri perlu diberikan pendidikan dan pelatihan agar bisa melakukan produksi agen hayati secara benar.

Berdasarkan uraian permasalahan yang dihadapi Madrasah Diniyah Jumapolo , maka ditawarkan solusi untuk mengembangkan agen hayati melalui peningkatan produksi. Dalam hal produksi, selain peningkatan kapasitas, maka juga perlu dilakukan pengemasan (packing) produk yang dihasilkan agar lebih marketable. Dalam kegiatan ini diusulkan untuk mengadakan pendampingan dalam produksi pestisida alami, baik insektisida maupun fungisida meskipun menggunakan peralatan ala kadarnya. Beberapa peralatan kecil seperti glassware dan bahan habis pakai (terutama bahan agar untuk menumbuhkan mikroba) telah diadakan untuk membantu produksi pestisida yang dimaksud.

Layaknya sebuah kegiatan bisnis, sisi manajemen dan keuangan juga perlu dibenahi sehingga peran dan fungsi masingmasing struktur dalam organisasi dapat menjalankan tugasnya dengan baik.

Di dalam pelaksanaan kegiatan, mitra berperan aktif dengan mengikuti semua rencana dalam agenda kegiatan yang telah disepakati. Pembuatan agen hayati, yaitu: Beauveria bassiana (sebagai bahan insektisida) dan Trichoderma sp.(sebagai bahan fungsida) ditingkatkan volumenya untuk memenuhi kebutuhan madrasah dan petani desa setempat. Mitra I, Ustadsz Abu Bakar Faqihuddin sebagai Direktur/Kepala Sekolah mempunyai kebijakan untuk pengembangan madrasah, baik secara akademik maupun non-akademik. Sedangkan Mitra II, Ustadz Nuruddin sebagai Kepala Divisi Pertanian di Madrasah Jumapolo, bertanggungjawab terhadap seluruh kegiatan di bidang pertanian organik. Kesuksesan dalam teknik produksi agen hayati akan membawa dampak positif bagi masyarakat sekitar yang pada gilirannya akan mengikuti bercocok tanam secara organik.

Hampir di setiap musim panen para petani mengalami kerugian akibat serangan hama. Serangan hebat hama wereng terjadi pada tahun 2010. Jika diteliti, meningkatnya serangan hama wereng kemungkinan disebabkan oleh:

1. Perubahan iklim sehingga kelembaban udara cukup tinggi (di musim kemarau)

2. Penggunaan pestisida yang tidak tepat dan berlebihan yang menyebabkan matinya predator alami dan terjadinya resistensi berbagai jenis hama termasuk wereng.

Penggunaan agen hayati merupakan salah satu solusi untuk mengantisipasi serangan hama wereng. Banyak agen hayati yang sudah dikembangkan, namun yang populer adalah B. bassiana dan Trichoderma sp. B. bassiana termasuk jamur entomopatogen, artinya dapat menimbulkan penyakit pada serangga. Jenis jamur ini menginfeksi tubuh serangga dimulai dengan kontak inang, masuk ke dalam tubuh inang, kemudian kontak dan menginfeksi inang baru [1]. Serangga yang terinfeksi jamur $B$. bassiana akan mati dengan tubuh mengeras seperti mumi dan warna putih jamur menutupi tubuh inang. Selanjutnya keadaan ini akan mengkontaminasi lingkungan, baik melalui spora menembus kutikula keluar tubuh inang maupun melalui feses yang sudah terkontaminasi. 


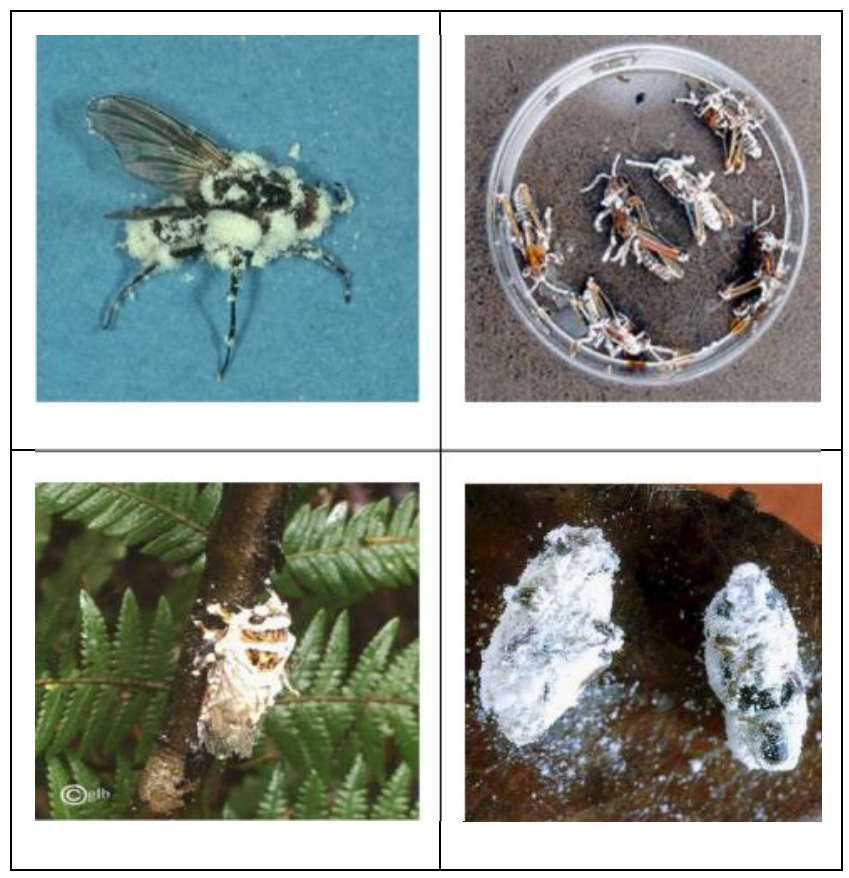

Gambar 1. Contoh serangga-serangga yang terinfeksi B. Bassiana [6,8]

B. bassiana merupakan parasit agresif untuk berbagai jenis serangga dan menyerang baik dalam tahapan larva maupun usia serangga dewasa. Spora B. bassiana sangat kecil, hanya beberapa micron. Hifa dan spora tidak berpigmen sehingga koloni tampak berwarna putih [5].

Secara alami, B. bassiana terdapat di dalam tanah sebagai jamur saprofit. Kondisi tanah seperti kandungan bahan organik, suhu, kelembaban, dan pola makan serangga dapat mempengaruhi pertumbuhan jamur di dalam tanah. Berdasarkan penelitian, jamur ini efektif untuk mengendalikan serangan hama walang sangit (Leptocorisa oratorius) dan wereng batang coklat (Nilaparvata lugens) pada tanaman padi serta hama kutu (Aphis sp.) pada tanaman sayuran [1,4]. Selain dengan penyemprotan, cara penanggulangan hama ini dapat dilakukan dengan metode jebakan hama, yaitu dengan memasukkan spora $B$. bassiana ke dalam botol beserta alat pemikat berupa aroma (feromon). Ketika seranggan tertarik masuk, maka dengan mudah akan terinfeksi.

Trichoderma sp. yang banyak ditemukan di tanah hutan/pertanian maupun pada substrat berkayu adalah termasuk dalam kelompok jamur ascomycetes yang memiliki sifat antifungal. Sifat antagonis terhadap jamur lainnya ini kemudian dikembangkan untuk biokontrol pertumbuhan jamur yang bersifat patogen. Aktivitas antagonis tersebut meliputi persaingan parasitisme, predasi, maupun pembentukan toksin [3]. Karena sifat-sfat inilah maka isolat Trichoderma sp. dikenal sebagai biofungisida alami. 


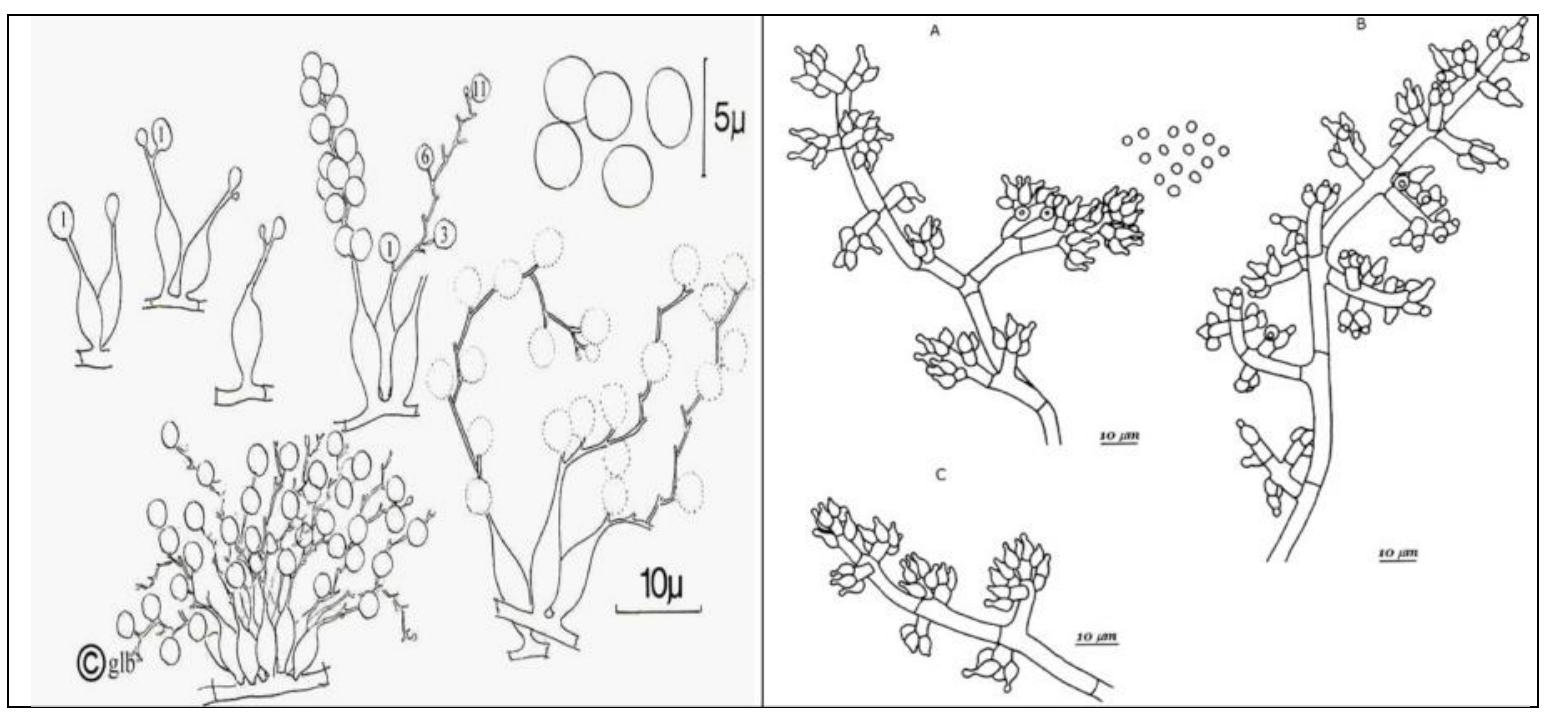

Gambar 2. Susunan spora dan morfologi B. bassiana [8] dan Trichoderma sp [9]

Selain sebagai agen hayati, spesies Trichoderma dapat berperan sebagai organisme pengurai dan stimulator pertumbuhan tanaman. Beberapa spesies Trichoderma telah dilaporkan sebagai agensia hayati seperti $T$. harzianum, $T$. viridae, dan T. konigii yang berspektrum luas pada berbagai tanaman pertanian. Biakan jamur Trichoderma dalam media aplikatif seperti dedak dapat diberikan ke areal pertanaman dan berlaku sebagai biodekomposer, mendekomposisi limbah organik (dedaunan dan ranting tua) menjadi kompos yang bermutu.

Penggunaan pestisida kimiawi/ sintetis adalah kurang bijaksana untuk pengendalian hama. Dampak negatif yang mungkin timbul di antaranya resistensi hama terhadap pestisida sintetis, munculnya residu pestisida, mengakibatkan pencemaran lingkungan, kontaminasi ke dalam tubuh manusia/binatang yang mengkonsumsi pestisida dan lain-lain. Sangatlah bijaksana apabila dalam pengendalian hama dilakukan dengan menggunakan musuh alami atau yang dikenal dengan agen hayati. Agen hayati adalah mikroorganisme, baik yang terjadi secara alami (bakteri, cendawan, virus dan protozoa) maupun hasil rekayasa genetik yang digunakan untuk mengendalikan hama. Dalam perkembangannya agen hayati tidak hanya meliputi mikroorganisme, tetapi juga organisme yang ukurannya lebih besar dan dapat dilihat secara kasat mata seperti predator atau parasitoid untuk membunuh serangga. Penggunaan insektisida dan fungisida alami dari agen hayati sebagai pemberantas hama penyakit merupakan salah satu bentuk penerapan pertanian organik yang menekankan aspek lingkungan, sosial dan ekonomi secara berkesinambungan. Pertanian organik tanpa bahan kimia akan menghasilkan bahan pangan yang sehat.

Kegiatan pengabdian masyarakat ini bertujuan untuk memberikan penyuluhan dan pendampingan dalam memproduksi agen hayati Beauveria bassiana dan Trichoderma sp. kepada para ustadz dan siswa-siswa di Madrasah Diniyah Jumapolo. Kegiatan yang diadakan meliputi pelatihan dalam manajemen, pengembangan produksi, baik dari segi kualitas dan kuantitas, serta pembinaan administrasi.

Jenis agen hayati yang dikembangkan dalam kegiatan ini adalah: 
1. Jamur B. bassiana untuk mengendalikan hama walang sangit dan wereng tanaman padi, dan kutu pada sayuran.

2. Jamur Trichoderma sp. untuk mengendalikan Fusarium oxysporum (penyebab penyakit busuk batang pada tanaman vanili), Phytophtora sp (penyebab penyakit busuk pangkal batang pada tanaman lada) dan Rigidoporus lignosus (penyebab penyakit jamur akar putih pada tanaman karet).

Manfaat dari kegiatan pengabdian masyarakat ini adalah (1) meningkatnya pemahaman para ustadz dan siswa-siswa Madrasah Diniyah Jumapolo dalam hal teknologi mikrobiologi termasuk inkubasi dan sterilisasi sehingga dapat meningkatkan kualitas dan kuantitas produksi, (2) menghasilkan hasil produksi berupa insektisida alami B. bassiana dan fungisida alami Trichoderma sp. dalam bentuk padatan yang siap dipasarkan, dan (3) secara umum pengembangan agen hayati dapat mengurangi penggunaan pestisida kimia sehingga dapat mengembalikan keseimbangan ekosistem di alam.

\section{METODE PELAKSANAAN}

Program pengabdian masyarakat di Madrasah Diniyah Jumapolo ini mempunyai tujuan untuk mengembangkan agen hayati baik di sektor peningkatan produksi maupun manajemen di Madrasah Diniyah Jumapolo, Karanganyar. Pembuatan agen hayati dimulai dari penyiapan starter.

Bahan yang digunakan dalam kegiatan ini adalah isolat murni agen hayati berbagai jenis, potato dextrose agar (PDA) atau saboroud dextrose agar (SDA), aquades, spirtus, alkohol, $\mathrm{NaOCl}$, kertas isap, tissu gulung, alumunium foil, kain kasa, gas elpiji, plastik, kapas dan lain-lain. Bahan agar dapat digantikan dengan beras jagung.

Alat yang digunakan adalah otoklaf, box isolasi, lampu bunsen, mikroskop, kaca obyek, kaca preparat, cawan petri, erlenmeyer, tabung reaksi, disecting set, panci serbaguna, baskom plastik, timbangan, semprotan kecil, saringan, spidol, hekter, baki plastik, dan rak penyimpanan.

Cara kerja pembuatan starter agen hayati adalah sebagai berikut:

- Menimbang beras jagung, mencuci bersih, selanjutnya mengukus dengan menggunakan dandang selama 30 menit ( $1 / 2$ matang).

- Menghamparkan beras jagung yang telah dikukus di atas nampan/baki sampai dingin. Untuk mempercepat pendinginan dapat digunakan kipas angin.

- Memasukkan masing-masing 100 gram ke dalam kantong plastik, hasil kemasan tersebut dimasukkan lagi ke dalam kantong plastik yang lebih besar, misalnya kapasitas $3 \mathrm{~kg}$.

- Mensterilkan bahan tadi di dalam otoklaf pada temperatur $121^{\circ} \mathrm{C}$, tekanan $15 \mathrm{psi}$ dan menjaga konstan selama 60 menit.

- Setelah steril, bahan diangkat dan didinginkan.

- Pada media beras jagung yang steril tersebut dilakukan inokulasi isolat murni agen hayati dengan menggunakan jarum ose. Pelaksanaan dilakukan di dalam boks isolasi secara aseptis.

- Selanjutnya plastik dihekter dan dikocok agar spora jamur dapat tersebar merata pada media jagung.

- Menginkubasikan pada suhu kamar selama \pm 2 minggu.

- Starter siap disalurkan dan digunakan untuk perbanyakan di tingkat petani.

Starter yang sudah terbentuk kemudian diaplikasikan di lapangan. Pelaksanaan aplikasi agen hayati di lapangan dilaksanakan dengan cara sbb.:

a. Jamur Beauveria bassiana

- Inokulum jamur ditambahkan air dan diremas-remas hingga sporanya 
terlepas. Kemudian disaring dan dimasukkan ke dalam sprayer.

- Dosisnya 4-8 kg inokulum dicampur dengan 250 - 400 liter air untuk lahan seluas $1 \mathrm{Ha}$.

- Aplikasi sebaiknya dilakukan pada pagi hari atau sore hari.

- Untuk jamur B. bassiana penyemprotan sebaiknya diarahkan pada tajuk tanaman.

b. Jamur Trichoderma sp

- Membuka tanah sekeliling leher akar sedalam $10-15 \mathrm{~cm}$ dan radius $20 \mathrm{~cm}$ dari pangkal batang, misalnya tanaman vanili.

- Menyebarkan formulasi Trichoderma sp ke sekeliling akar. Dapat juga dioleskan pada batang vanili yang terserang penyakit layu Fusarium.

- Menutup kembali leher akar dengan tanah bongkaran.

- Tanah harus dalam kondisi basah agar jamur berkembang dengan sempurna.

- Dosis yang digunakan adalah 50 gram / pohon untuk tanaman pada polybag, 100 gram / pohon untuk tanaman yang belum menghasilkan, dan 150 gram / pohon untuk tanaman yang sudah menghasilkan.

Sumber dari BLH Grobogan [2] menyebutkan pelaksanaan penggunaan Trichoderma sbb.:

- Untuk aplikasi Trichoderma sp pada pesemaian dilakukan dengan cara mencampur Trichoderma : tanah : pupuk kandang dengan perbandingan $1: 2: 1$

- Aplikasi pada pertanaman di lapangan dilakukan dengan cara bersamaan dengan pupuk dasar atau dicampur dengan pupuk kandang dengan dosis 10 - 20 gr jamur Trichoderma sp per lubang atau $140 \mathrm{~kg}$ per hektar.

- Cara aplikasi pada tanaman tahunan (jeruk, mangga, durian, alpukat dll) dilakukan dengan cara mencampur Trichoderma sp dengan pupuk kandang lalu ditaburkan pada lubang di sekitar perakaran dengan dosis $1-4 \mathrm{~kg}$ per tanaman.

\section{HASIL DAN PEMBAHASAN \\ A. Evaluasi}

Penerapan agen hayati di bidang pemberantasan hama memiliki kelebihan karena sesuai dengan prinsip keseimbangan ekosistem dengan cara memanfaatkan musuh alami dari hama dan penyakit pengganggu tanaman. Banyak pengalaman menunjukkan bahwa dalam pengendalian penyakit layu pada tanaman seperti cabai, tomat dan kentang sudah tidak mampu lagi dikendalikan dengan obat-obatan kimia pembasmi hama dan dimungkinkan untuk dibasmi menggunakan agen hayati.

\section{kelebihan, yaitu:}

Agen hayati memiliki banyak

1. Bersifat selektif. Artinya agen hayati hanya akan menyerang hama penyakit sasaran dan mikroba dalam agen hayati tidak akan menyerang organisme yang bermanfaat bagi tanaman.

2. Mampu mencari sasaran sendiri. Agen hayati adalah makhluk hidup yang bersifat patogen bagi organisme pengganggu sehingga agen hayati mampu secara alami menemukan hama dan penyakit sasarannya.

3. Tersedia di alam. Secara alami agen hayati sudah tersedia di alam, namun karena penggunaan pestisida yang tidak sesuai menyebabkan keseimbangan ekosistem mulai goyah dan populasinya terganggu.

4. Tidak ada efek samping. Produk tanaman yang dihasilkan tidak terkontaminasi bahan kimia.

5. Relatif murah. 
Namun selain kelebihan-kelebihan di atas, agen hayati juga memiliki kekurangan-kekurangan, yaitu:

1. Bekerja lambat. Kondisi ini seringkali menyebabkan petani tidak sabar menunggu hasilnya dan menganggap agen hayati tidak manjur sehingga petani kembali beralih ke pestisida kimiawi.

2. Sulit diprediksi hasilnya. Perkembangbiakan agen hayati setelah diaplikasikan sangat dipengaruhi oleh ekosistem pada saat pengaplikasian. Jika kondisinya mendukung, maka pertumbuhan agen hayati akan maksimal.

3. Kurang cocok digunakan untuk usaha kuratif, apalagi saat terjadi ledakan hama karena agen hayati bekerja lambat. Agen hayati lebih optimal jika digunakan untuk usaha preventif karena membutuhkan waktu untuk pertumbuhannya.

4. Sulit dikembangkan secara missal untuk jenis agen hayati tertentu.

5. Penggunaan agen hayati harus sesering mungkin.

\section{B. Indikator Keberhasilan Program}

Keberhasilan program Pakom ini dapat dilihat dari beberapa indikator yang sesuai dengan rencana yang telah ditetapkan sebelumnya. Indikator keberhasilan tersebut adalah sebagai berikut:

(1. Peningkatan pemahaman teknologi mikrobiologi termasuk inkubasi dan sterilisasi

Para ustad dan siswa-siswa dapat memahami secara baik tentang prosedur teknologi di bidang mikrobiologi khususnya sterilisasi dan inkubasi. Meskipun terdapat kendala di peralatan yang masih sangat sederhana, namun kegiatan pembuatan agen hayati dapat berjalan dan secara kualitas dan kuantitas juga meningkat.

(2. Terbentuk hasil produksi berupa insektisida alami $B$. bassiana dan fungisida alami Trichoderma sp. dalam bentuk padatan yang siap dipasarkan.

Pembuatan agen hayati yang dikembangkan telah berhasil membuat produk agen hayati

\section{Keberlanjutan Program}

Perlu dilanjutkan dalam kegiatan yang lebih besar dengan konsekuensi pendanaan yang cukup untuk pembelian peralatan produksi agar program pembuatan agen hayati dapat meningkat secara signifikan dalam hal kualitas dan kuantitas sehingga produk agen hayati tersebut dapat dijual ke masyarakat secara luas dan menjadi sumber penghasilan bagi madrasah.

\section{SIMPULAN}

\section{Simpulan}

Agen hayati $B$. bassiana dan Trichoderma sp dapat digunakan untuk mengendalikan hama tanaman. Penggunaan agen hayati diyakini memiliki kelebihan karena sesuai dengan prinsip keseimbangan ekosistem dengan memanfaatkan musuh alami dari hama dan penyakit pengganggu tanaman pertanian. Meskipun demikian, penggunaan agen hayati juga memiliki keterbatasan, misalnya ketika serangan hama sudah dalam kondisi akut atau parah. Namun yang perlu dicatat adalah bahwa dengan penggunaan agensia hayati akan bisa menghemat penggunaan pupuk dan pestisida kimia.

Produksi agen hayati telah berhasil dilakukan di Madrasah Diniyah Jumapolo Karanganyar. Pengembangan produksi masih perlu ditingkatkan secara kualitas dan kuantitas agar penggunaan agen hayati makin meluas sehingga dapat mengurangi ketergantungan pada pestisida kimia sekaligus juga mengembangkan pertanian organik dan juga memberikan nilai ekonomi bagi para santri madrasah tersebut. 


\section{B. Saran}

Kegiatan pengabdian masyarakat untuk mengembangkan agen hayati perlu dilanjutkan untuk membantu petani sekaligus mengurangi dampak penggunaan pestisida kimiawi. Untuk mendapatkan hasil yang signifikan dalam produksi, maka sebaiknya diberikan pendanaan yang lebih besar untuk membantu pengadaan bahan dan peralatan.

\section{PERSANTUNAN}

Tim Pengabdian Masyarakat Kompetitif mengucapkan terima kasih kepada Ustadz Abu Bakar Faqihudin selaku Kepala Madrasah Diniyah Jumapolo, Ustadz Nurudin selaku Kepala Divisi Pertanian Madrasah Diniyah Jumapolo dan para ustadz dan siswa-siswa yang membantu kelancaran kegiatan pengabdian masyarakat, Dr. Muhtadi, M.Si. selaku reviewer program Pakom, serta LPPM UMS yang mendanai kegiatan ini.

\section{DAFTAR PUSTAKA}

1. Balai Penelitian Tanaman Hias (BPTH), 2006. Beauveria bassiana pengendali hama tanaman. Warta Penelitian dan Pengembangan Pertanian Indonesia 28(1): 11-12.

2. BLH Grobogan, 2011, Kelebihan dan kekurangan agen hayati, http://blh.grobogan.go.id/ artikel/377-kelbihan-dan-kekurangan-agen-hayati.html, diakses 12 November 2013

3. Carpenter MA, Ridgway HJ, Stringer AM, Hay AJ, Stewart A. 2008. Characterisation of a Trichoderma hamatum monooxygenase gene involved in antagonistic activity against fungal plant pathogens. Curr Genet 53:193-205.

4. Dinas Pertanian Propinsi DIY. 2005. Beauveria bassiana pengendaali walang sangit. http:/ /www.distan.pemda-diy.go.id/index.php?option=content $\&$ task=view \&id=92\& Itemid=2, diakses 12 September 2013.

5. Roberto, M.P. dan W.R. Donald.1990. Dray Mycelium Praparation of Entomophatogenic Fungi Metarhizium anisopliae and Beauveria bassiana, J. Invertebrate Phatology, 56, 39-46, Academic Press, Inc.

6. Sevas Educational Society, 2007, Production of bioinsecticides, http:// www.sbioinformatics.com/Bioinsecticides.html, diakses 16 September 2013

7. Suwahyono, U., dan P. Wahyudi, 2008, Produksi dan Formulasi Bioinsektisida dari Propagul Aktif Jamur Beauveria bassiana, J. Tek. Ling, 9(1), 85-91

8. University of Guelph, Canada, 2013, Beauveria bassiana, http://www.uoguelph.ca/ gbarron/ MISCELLANEOUS/nov01.htm, diakses 15 Desember 2013

9. Kraus, Gunther F., et al, 2004, Trichoderma brevicompactum sp. Nov, Mycologia, September/October 2004 vol. 96 no. 5, 1059-1073 